\title{
Koi Herpesvirus Disease (KHVD) ${ }^{1}$
}

\author{
Kathleen H. Hartman, Roy P.E. Yanong, Deborah B. Pouder, B. Denise Petty, Ruth Francis-Floyd, \\ Allen C. Riggs, and Thomas B. Waltzek ${ }^{2}$
}

\section{Introduction}

Koi herpesvirus (KHV) is a highly contagious virus that causes significant morbidity and mortality in common carp (Cyprinus carpio) varieties (Hedrick et al. 2000, Haenen et al. 2004). Common carp is raised as a foodfish in many countries and has also been selectively bred for the ornamental fish industry where it is known as koi. The first recognized case of KHV occurred in the United Kingdom in 1996 (Haenen et al. 2004). Since then other cases have been confirmed in almost all countries that culture koi and/ or common carp with the exception of Australia (Hedrick et al. 2000; Haenen et al. 2004, Pokorova et al. 2005). This information sheet is intended to inform veterinarians, biologists, fish producers and hobbyists about KHV disease.

\section{What Is KHV?}

Koi herpesvirus (also known as Cyprinid herpesvirus 3; $\mathrm{CyHV} 3$ ) is classified as a double-stranded DNA virus belonging to the family Alloherpesviridae (which includes fish herpesviruses). The work of Waltzek and colleagues (Waltzek et al. 2005, 2009) revealed that KHV is indeed a

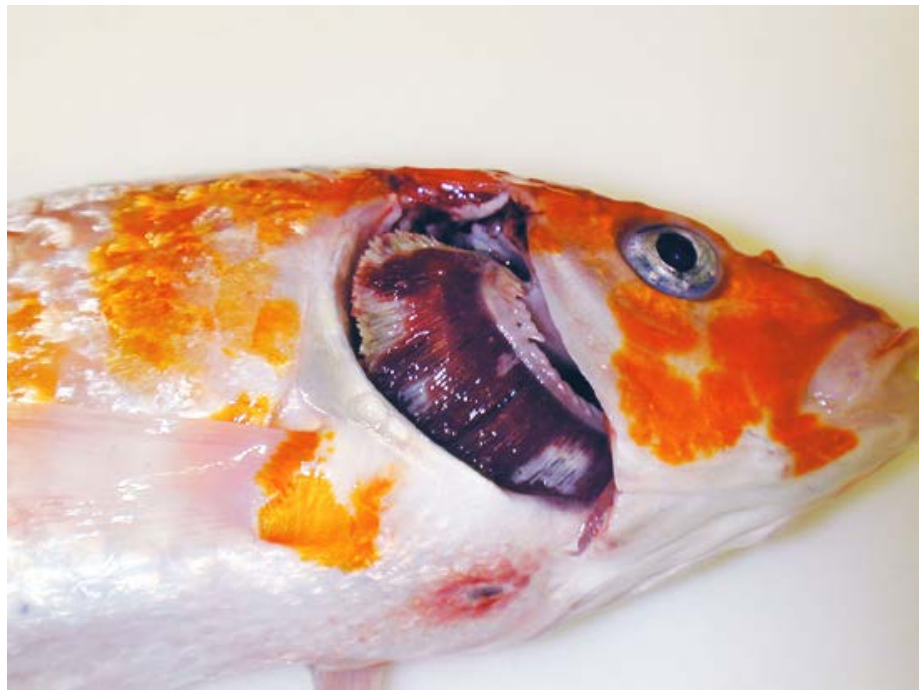

Figure 1. Koi with mottled gills and sunken eyes due to koi herpesvirus disease. Credit: Deborah B. Pouder, University of Florida

herpesvirus, based on virus morphology and genetics, and is closely related to carp pox virus (Cyprinid herpesvirus 1; CyHV1) and goldfish hematopoietic necrosis virus (Cyprinid herpesvirus 2; CyHV2). Koi herpesvirus disease has been diagnosed in koi and common carp (Hedrick

1. This document is Fact Sheet VM-149, one of a series from the School of Forest Rescources and Conservation Program in Fisheries and Aquatic Sciences and the Department of Large Animal Clinical Sciences (College of Veterinary Medicine), Florida Cooperative Extension Service, Institute of Food and Agricultural Sciences, University of Florida. First published: June 2004. Revised April 2013. Please visit the EDIS website at http://edis.ifas.ufl.edu.

2. Kathleen H. Hartman, courtesy assistant professor; Roy P.E. Yanong, associate professor/Extension veterinarian; and Deborah B. Pouder, coordinator of research programs and services, Tropical Aquaculture Laboratory, Program in Fisheries and Aquatic Sciences (School of Forest Resources and Conservation), Florida Cooperative Extension Service, Institute of Food and Agricultural Sciences, University of Florida, Ruskin, FL 33570. B. Denise Petty, clinical assistant professor; and Ruth Francis-Floyd, professor, Department of Large Animal Clinical Sciences (College of Veterinary Medicine) and Program in Fisheries and Aquatic Sciences (School of Forest Resources and Conservation), Florida Cooperative Extension Service, Institute of Food and Agricultural Sciences, University of Florida, Gainesville, FL 32611. Allen C. Riggs, Covington, KY 41011. Thomas B. Waltzek, assistant professor, Department of Infectious Diseases and Pathology, College of Veterinary Medicine, University of Florida, Gainesville, FL 32610, USA.

The use of trade names in this publication is solely for the purpose of providing specific information. UF/IFAS does not guarantee or warranty the products named, and references to them in this publication does not signify our approval to the exclusion of other products of suitable composition.

The Institute of Food and Agricultural Sciences (IFAS) is an Equal Opportunity Institution authorized to provide research, educational information and other services only to individuals and institutions that function with non-discrimination with respect to race, creed, color, religion, age, disability, sex, sexual orientation, marital status, national origin, political opinions or affiliations. U.S. Department of Agriculture, Cooperative Extension Service, University of Florida, IFAS, Florida A\&M University Cooperative Extension Program, and Boards of County Commissioners Cooperating. Nick T. Place, Dean 
et al. 2000; OATA 2001). Other cyprinids (e.g., goldfish; Carassius auratus and grass carp; Ctenopharyngodon idella) and non-cyprinid species are typically unaffected by KHV, although KHV DNA has been detected in the tissues of goldfish and other fish species exposed to the virus using polymerase chain reaction (PCR) testing methods (El-Matbouli et al. 2007, Sadler et al. 2008, Bergmann et al. 2009, Kempter et al. 2009). Hybrid goldfish (male goldfish C. auratus $\mathrm{x}$ female common carp C. carpio) were moderately resistant to mortality following experimental infection with KHV (Hedrick et al. 2006). Whether hybrid common carp, other cyprinids, or non-cyprinid species can harbor $\mathrm{KHV}$ and later transmit the disease to naïve common carp varieties remains controversial.

Koi herpesvirus disease (KHVD) affects fish of various ages, often resulting in $80-100 \%$ mortality in susceptible populations when water temperatures are between $60^{\circ}$ and $77^{\circ} \mathrm{F}\left(16^{\circ}\right.$ and $\left.25^{\circ} \mathrm{C}\right)$ (Haenen et al. 2004). However, as with other herpesviral infections, KHV may remain in the infected fish for life; therefore, fish that recover from a KHV outbreak should be considered as carriers of the virus (Petty and Fraser 2005, St. Hilaire et al. 2005, Eide et al. 2011).

\section{What are the signs of KHV?}

Clinical signs of KHV are often non-specific. Mortality may begin very rapidly in infected populations, with deaths starting within 24 to 48 hours after the initial onset of clinical signs. In experimental studies, $82 \%$ of fish exposed to the virus at a water temperature of $72^{\circ} \mathrm{F}\left(22^{\circ} \mathrm{C}\right)$ died within the first 15 days (Ronen et al. 2003). KHV infection may produce severe gill lesions which exhibit as gill mottling with red and white patches (Figure 1) (may be similar to columnaris disease signs; SRAC publication \#479b on Columnaris Disease). The white patches are due to necrosis (death) of the gill tissue. Gill lesions caused by KHV disease are the most common clinical signs in affected koi. Other external signs of KHV may include bleeding gills, sunken eyes, and pale patches on the skin. Some KHV infected koi may have a notched nose (Goodwin 2012). In some cases, secondary bacterial and parasitic infections may be the most obvious problem, masking the damage caused by the primary viral infection. Microscopic examination of gill biopsies often reveals high numbers of bacteria and various parasites (Hedrick et al. 2000; Haenen et al. 2004).

Internal signs of KHVD are variable and non-specific but may include greater than normal adhesions in the body cavity and enlargement and/or mottled appearance of internal organs (Hedrick et al. 2000; Haenen et al 2004).
Behaviorally, affected fish often remain near the surface, swim lethargically and may exhibit respiratory distress and uncoordinated swimming.

\section{How do fish get infected with KHV?}

Methods of spreading (transmission) of KHV include direct contact with infected fish, contact with fluids from infected fish; and contact with water, mud, or other fomites/vectors that have come into contact with contaminated systems. The infectious virus primarily enters susceptible fish through the skin, including gill tissue (Costes et al. 2009). Depending upon water temperature, susceptible fish that are exposed to KHV may either become infected, develop disease, and die; or they may survive the initial outbreak of the disease and become carriers of the virus (Petty and Fraser 2005, St. Hilaire et al. 2005, Eide et al. 2011). Fish that survive exposure to KHV or receive the KHV vaccine may become immunized and develop a level of protection against the virus, although the length of protection remains unknown (Ronen et al. 2003, Perelberg et al. 2008). Survivors of KHV outbreaks may become carriers of the virus and may be capable of spreading the disease to susceptible fish. These carrier fish may not show signs of KHV infection although they may be carrying and/or shedding the virus.

\section{How does water temperature affect KHV disease?}

KHV disease (KHVD) outbreaks typically occur in spring and autumn when water temperatures are between $60^{\circ}$ and $77^{\circ} \mathrm{F}\left(16^{\circ}\right.$ and $\left.25^{\circ} \mathrm{C}\right)$ with an incubation period of 7-21 days depending upon water temperature (Haenen et al. 2004). KHVD at temperatures as low as $60^{\circ} \mathrm{F}(15.5-$ $16^{\circ} \mathrm{C}$ ) has been reported in common carp outbreaks in Japan, and experimental trials have shown that the virus can induce mortality up to about $82^{\circ} \mathrm{F}\left(28^{\circ} \mathrm{C}\right)$. Warmer water temperatures more rapidly induce clinical disease as compared to fish held at lower temperatures. At lower water temperatures (e.g., $55^{\circ} \mathrm{F}\left[13^{\circ} \mathrm{C}\right]$ ), the virus can infect fish without inducing clinical signs of disease, but when permissive water temperatures are again experienced, the fish show typical KHV signs and may die (Gilad et al. 2003, St. Hilaire et al. 2005).

\section{How do I know if my fish have KHV?}

Positive diagnosis of KHV requires the assistance of a veterinarian or fish health specialist and a fish disease 
diagnostic laboratory. Diagnostic identification of KHV may be accomplished by several direct and indirect methods. Direct methods are procedures that detect actual virus or "pieces" of virus. Indirect methods are procedures that determine whether a fish has mounted an immune response against KHV following exposure to virus by measuring anti-KHV antibody levels in the blood (Adkison et al. 2005, St-Hilaire et al. 2005, 2009).

Direct methods used to identify KHV include: 1) virus isolation and identification (i.e., growing the virus) using a susceptible cell line such as the Koi Fin (KF-1) cell line \{optimal growth observed at temperatures between $59^{\circ}$ and $77^{\circ} \mathrm{F}\left(15^{\circ}\right.$ and $\left.\left.25^{\circ} \mathrm{C}\right)\right\}$ and 2) PCR techniques (i.e., testing for the presence of KHV DNA). For these direct diagnostic tests, tissues are removed from fish that are collected alive then euthanized. Isolation and detection of the virus in tissues from fish dead longer than a few hours may be unreliable. Non-lethal direct diagnostic tests are available on samples such as blood, fecal material, mucus and gill clips (i.e., biopsies), but these tests may yield less definitive or less accurate results. A positive cell culture test indicates an active, ongoing infection with KHV. Positive detection of KHV DNA using PCR indicates that the virus is present, so it can be used to confirm KHV disease in clinically sick fish and perhaps even to identify carriers (Eide et al. 2011).

One indirect testing method for KHV that has been widely used is the enzyme-linked immunosorbent assay (ELISA). The KHV ELISA uses a blood sample and, therefore, is a non-lethal diagnostic tool. ELISA data can provide evidence that a fish is currently mounting, or has previously mounted, an immune response (i.e., production of antibodies) against KHV. A positive ELISA test for KHV indicates that the fish has produced antibodies against KHV after a previous exposure to the virus. However, antibodyproducing immune cells take time to become activated, and over time, if a fish is no longer sick, anti-KHV antibody production may slow down or stop. Therefore, ELISA may not be able to detect antibodies to KHV if the infection occurred years before or if the fish has not yet had time to produce antibodies.

Negative results by either direct or indirect tests do not necessarily mean fish are not carriers. There is no test that definitively detects all carriers or survivors.

\section{Is there treatment for KHV?}

There is no treatment for KHV. Antiviral drugs are not available to treat KHV or any other viral diseases of cultured fish. Studies have shown that koi may survive an outbreak of KHV if water temperatures are increased to $86^{\circ} \mathrm{F}\left(30^{\circ} \mathrm{C}\right)$ during the outbreak (Ronen et al. 2003). However, this technique only marginally increases survival rates, and artificially raising water temperatures above $80^{\circ} \mathrm{F}$ in holding facilities may result in an increased occurrence of other more common bacterial and parasitic diseases. High water temperatures are not generally recommended for routine husbandry and management of koi and common carp. In addition, and more importantly, koi which survive a KHV outbreak or those exposed at high water temperatures may become carriers of the virus. These carrier koi are a source of the disease to susceptible fish when conditions are appropriate for viral shedding and infection. Due to previous exposure and immunization to the virus, carrier fish will typically not succumb to KHV disease or show signs of clinical infection.

Recently, USDA APHIS approved the use of an attenuated live vaccine for prevention of KHVD, to be administered to common carp or koi heavier than 100 grams (the vaccine is not approved for use in broodstock). The vaccine, originally developed by an Israeli research group (Ronen et al. 2003), generates high anti-KHV antibody titers and protects vaccinated common carp or koi upon subsequent viral challenge (Ronen et al. 2003, Perelberg et al. 2008). However, concerns have been raised regarding the efficacy of the vaccine and the length of protection afforded vaccinated fish. Currently, it is unknown whether vaccinated fish become carriers of the vaccine strain or if they are protected against infection by the wild-type strain which would pose a threat to unvaccinated common carp. Another challenge with regards to the vaccine is that no diagnostic tests are commercially available that can differentiate vaccinated versus naturally infected/exposed fish.

Because KHV outbreaks have caused large losses at koi and common carp facilities and because there is concern that survivors are carriers, anyone with koi that have been diagnosed with KHV should consider depopulation (eliminating the entire population) as a logical option. All materials and systems that the infected fish have contacted should be cleaned and disinfected.

Viral particles in environmental water may remain infectious for up to three days (Shimizu et al. 2006). However, common disinfection protocols (see below) may be used to eliminate the virus from water systems and equipment. Biofilters and biofilter media exposed to the virus should also be thoroughly cleaned and disinfected. Prior to disinfection, equipment should be cleaned of debris or organic build-up, as these may reduce the effectiveness of the disinfectant. Chlorine solutions (e.g., household bleach) may be used to disinfect large equipment or systems 
without fish. The recommended protocol for chlorine is 200 ppm (200 mg/L) for one hour (Noga 1996). Proper dosing of this active ingredient depends upon the type of chlorine used. For household bleach, which is $5.25 \%$ sodium hypochlorite per liter, 35 milliliters per gallon of water will give $200 \mathrm{mg} / \mathrm{L}$ final concentration.

Quaternary ammonium compounds (QACs) may also be used for systems and equipment. Quaternary ammonium compounds are gentler on nets than chlorine solutions. The recommended QAC concentration for disinfection is 500 ppm (500 mg/L) for one hour (Noga 1996). Proper dosing of QACs depends upon the type/concentration in the mixture used because concentrations will vary depending upon the product used. Different QAC products may range from $10 \%$ to $50 \%$ active ingredient. For example, Roccal-D Plus $^{\circledast}$ (Pharmacia \& Upjohn Company, Pfizer) is approximately $24 \%$ active ingredient; therefore, a final treatment concentration of $500 \mathrm{mg} / \mathrm{L}$ would require about $7.9 \mathrm{~mL}$ of Roccal-D Plus ${ }^{\circledast}$ per gallon of water. Rinse thoroughly after use of any type of disinfectant to eliminate residual disinfectant which may kill fish.

\section{How can KHV be prevented?}

Prior to obtaining any fish, first ask the supplier if there have been any major unexplained losses in the population. Monitoring and testing for KHV may be done by laboratory tests, so ask suppliers if any testing for KHV has been done and request a copy of lab result documentation. The best way to prevent KHV is to know your fish suppliers and to have a good working relationship with them.

Quarantine (that is, separation from other koi) is the most dependable method to avoid the introduction of pathogens into a pond or facility. To implement an effective quarantine procedure, all new fish must be kept in a separate system, ideally in a different building or area from the resident fish. Resident fish should be fed, handled, and maintained before the new fish. The quarantined fish require dedicated equipment such as nets, buckets, and siphon hoses that are used only for them. In addition, foot baths and hand washes should be used by anyone entering and leaving the quarantine area. Fish should be quarantined for a minimum of 30 days. Specifically for KHV, new koi should be quarantined in water that is $75^{\circ} \mathrm{F}\left(24^{\circ} \mathrm{C}\right)$ for at least 30 days. At the conclusion of the quarantine period, any sick fish should be examined by a veterinarian and/or diagnostic lab to rule out KHV or other diseases. If all fish appear healthy, blood samples should be collected from these quarantined fish and submitted for antibody detection using ELISA. (Atkinson et al. 2005; St. Hilaire et al. 2009)
Koi hobbyists are encouraged to promote the use of English-style koi shows, which keep different sources (owners) of koi separated during the show and judging. Additionally, separate nets, siphon hoses, and other equipment should be used by all show participants for their own fish. The Japanese-style of show, in which koi from different owners are placed together in the same tank, may result in the spread of disease among susceptible fish. Regardless of the show style, fish returning from shows should be quarantined for a minimum of 30 days and held at $75^{\circ} \mathrm{F}$ prior to being placed back into the general population. For added security, blood sampling antibody testing may be helpful. Survivors (fish that have previously been exposed to KHV disease) should never be taken to a koi show.

At the end of the quarantine period and before placing all fish together, place several new koi with several koi from the established population in a separate area away from the rest of the established population and watch them for signs of disease. This "test" can help determine with a smaller number of fish whether placing the two populations together following quarantine could cause problems. Unfortunately, there are no guarantees.

\section{Whom should I contact if I suspect my fish have KHV or if I want more information?}

Commercial fish producers, wholesalers, and retailers in Florida may contact one of the following University of Florida Fish Disease Diagnostic Labs*:

\section{In north Florida:}

Thomas B. Waltzek

Wildlife and Aquatic Veterinary Disease Laboratory (WAVDL)

Aquatic Pathobiology

University of Florida

Bldg. 471, 2173 Mowry Road

Gainesville, Florida 32611

(352) 273-5202

Email: tbwaltzek@ufl.edu

\section{In south Florida:}

Roy P. E. Yanong or Deborah Pouder

Tropical Aquaculture Laboratory

Fish Disease Diagnostic Lab

University of Florida

1408 24th St. SE 33570

Ruskin, Florida

(813) 671-5230

http://tal.ifas.ufl.edu 
${ }^{\star}$ Please note: These labs accept cases from commercial fish producers, wholesalers and retailers only.

Hobbyists and personal koi pond owners (or commercial fish producers, wholesalers, and retailers outside Florida) may search for an aquatic veterinarian or aquatic diagnostic laboratory in their area on the AquaVetMed website (http:// www.aquavetmed.info) or http://www.myveterinarian.com/ avma/vclPublic/\#.

\section{What are the regulatory considerations associated with KHV?}

As of January 2007, KHV was added to the World Organization for Animal Health (OIE; www.oie.int) disease list for fish. Because of this listing the United States Department of Agriculture Animal and Plant Health Inspection Service (USDA APHIS) asks that accredited veterinarians and diagnostic laboratories report positive cases of KHV to the area veterinarian-in-charge (AVIC) of the state where the fish originated. However, no client information (e.g., name, address) will be requested. This information will help USDA determine what the prevalence of KHV is in the United States. USDA APHIS has no import health requirements specific for KHV for koi or other fish moving interstate or internationally. There is no mandatory depopulation for populations of koi infected with KHV. It is up to the owner of those animals and their veterinarian to decide what course to take.

Koi breeders, dealers, exhibitors, and veterinarians should be aware of international export health regulations regarding the movement of KHV-vaccinated fish. The import requirements for some countries specify that KHV-vaccinated fish will not be permitted entry. Please check the APHIS website for state and international health requirements (listed respectively):

http://www.aphis.usda.gov/animal_health/animal_dis_ spec/aquaculture/aquastates.shtml

http://www.aphis.usda.gov/regulations/vs/iregs/animals/

Or contact the local USDA APHIS VS Area Office for assistance (http://www.aphis.usda.gov/animal_health/ area_offices/).

\section{Can humans get KHV?}

There is no zoonotic concern with KHV. The herpesvirus responsible for causing KHV disease in fish will not cause disease in humans.

\section{How does KHV differ from other viral diseases?}

It is important to differentiate KHV from other viruses that may cause disease in carp and koi. Two other important viral diseases recognized in carp are spring viremia of carp (SVC) and carp pox (Cyprinid herpesvirus 1; CyHV1). These diseases have significantly different management and regulatory implications (Table 1). Both KHV and SVC are now listed as notifiable fish diseases by the OIE. However, within the U.S., SVC is considered a foreign or exotic (not present) fish disease of aquacultured susceptible species and, as such, the accredited veterinarian or laboratory is required to notify confirmed outbreaks to USDA APHIS Veterinary Services officials who will, in turn, notify the OIE. By comparison, KHV is considered to be widespread in the United States. USDA APHIS asks accredited veterinarians and laboratories to report cases of KHV to the area veterinarian-in-charge (AVIC) of the state where the outbreak is occurring. The information will help USDA determine what the true prevalence of KHV is in the U.S. However, every outbreak of KHV will not be notified to the OIE.

Spring viremia of carp disease is caused by a singlestranded RNA virus, Rhabdovirus carpio, and has been reported in common carp and koi (C. carpio), grass carp (C. idella), bighead carp (Aristichthys nobilis), silver carp (Hypophthalmichthys molitrix), Crucian carp (Carassius carassius) and common goldfish (C. auratus). For more information on SVC see Table 1 and the UF/IFAS fact sheet "Spring Viremia of Carp" (VM-142).

Carp pox disease (Cyprinid herpesvirus 1; CyHV1) is caused by a different herpesvirus from KHV (Herpesvirus cyprini) that has a wide geographic distribution and affects common carp and koi. Carp pox typically causes smooth raised growths ("wart-like masses") on skin and fins of older fish but may be associated with high mortality in fry less than two months of age (Sano et al. 1990). Carp pox is not a reportable or notifiable disease in the U.S. Water temperatures above $68^{\circ} \mathrm{F}\left(20^{\circ} \mathrm{C}\right)$ help reduce the skin and fin growths on older fish, but does not eliminate the virus from the fish (Table 1). In mature fish, carp pox is typically a non-lethal, self-limiting disease (i.e., most if not all growths will resolve at warmer temperatures on their own).

\section{Summary}

Koi herpesvirus disease is a devastating disease of ornamental koi and common carp. There are several methods to detect various states of the infection. There is no effective treatment to rid the fish of the virus. Good management 
practices, including quarantine, testing, and appropriate husbandry, are vital components to preventing this disease for all koi and common carp producers, dealers, and hobbyists.

\section{Glossary}

Adhesions: areas of internal tissues that stick together; may be normal in some species and a result of inflammation in others

Ascites: dropsy; a build-up of fluid in the body cavity

Asymptomatic: showing no signs of disease or infection

Attenuated: weakened; less pathogenic or less disease-causing

AVIC: USDA APHIS Area Veterinarian-In-Charge. There is one AVIC per state

Carrier: an animal that harbors a disease-causing agent in its body without showing clinical signs of infection (i.e., they appear healthy but are capable of spreading disease under the right conditions)

Clinical signs: the observed physical or behavioral abnormalities

CyHV1: Cyprinid herpesvirus 1; the virus that causes carp/ koi pox

CyHV2: Cyprinid herpesvirus 2; the virus that causes hematopoietic necrosis herpesvirus of goldfish

CyHV3: Cyprinid herpesvirus 3; the virus that causes koi herpesvirus

Common carp: Cyprinus carpio; common carp are the original species of fish from which koi were developed for ornamental purposes

Cyprinid herpesvirus 1: CyHV1; the virus that causes carp/ koi pox

Cyprinid herpesvirus 2: $\mathrm{CyHV} 2$; the virus that causes hematopoietic necrosis herpesvirus of goldfish

Cyprinid herpesvirus 3: CyHV3; the virus that causes koi herpesvirus

DNA: Deoxyribonucleic Acid; found in a cell's nucleus, DNA is the basic structure of genes

Edema: a buildup of fluids within tissues
ELISA: Enzyme-Linked Immunosorbent Assay; a lab method used to detect the presence of antibody to a virus

Fomite: an inanimate object or material (e.g., net, siphon hose) on which disease-causing agents may be spread

Gene: unit of heredity consisting of portions of DNA

Intracoelomic: within the body cavity

KHV: koi herpesvirus; the name of the virus that causes koi herpesvirus disease

Koi: a common carp that has been selectively bred for ornamental purposes

Morbidity: disease or sickness

Naïve fish: a fish that has not been exposed or infected by a pathogen

Necrosis: death of tissue

Necrotic: dead

Notifiable disease: a disease which must, by law, be reported to the proper federal (USDA APHIS Veterinary Services) and state (state veterinarian) officials when positively diagnosed

OATA: Ornamental Aquatic Trade Association; a British organization representing the interests of ornamental fish importers, breeders, wholesalers, retailers, and manufacturers

PCR: Polymerase Chain Reaction; an advanced molecular method used to identify the presence of specific pieces of an organism's genes (DNA)

Reportable disease: same as notifiable disease; a disease which must, by law, be reported to the proper federal (USDA APHIS Veterinary Services) and state (state veterinarian) officials when positively diagnosed

Self-limiting: does not cause major disease and usually heals or resolves on its own

SVC: spring viremia of carp

Transmission: the transfer of a pathogen from one animal to another

USDA APHIS: United States Department of Agriculture, Animal and Plant Health Inspection Service

Vector: a carrier (e.g., Argulus) which transfers an infective agent from one animal to another 
Virus neutralization (VN): a lab method used to quantitate antibody to a specific viral pathogen

Zoonotic: a disease of animals (e.g., fish) that can be spread to, and cause disease in humans

\section{References}

Bergmann SM, Schutze H, Fischer U, Fichtner D, Riechardt M, Meyer K, Schrudde D, Kempter J (2009b) Detection of koi herpes virus (KHV) genome in apparently healthy fish. Bulletin of the European Association of Fish Pathologists. 29:145-152.

Costes B, Stalin Raj V, Michel B, Fournier G, Thirion M, Gillet L, Mast J, Lieffrig F, Bremont M, Vanderplasschen A (2009) The major portal of entry of koi herpesvirus in Cyprinus carpio is the skin. J Virol 83:2819-2830.

Eide K, T Miller-Morgan, J Heidel, R Bildfell, L Jin (2011) Results of total DNA measurement in koi by tissue koi herpesvirus real-time PCR. Journal of Virological Methods 172:81-84.

El-Matbouli M, Saleh M, Soliman H (2007) Detection of cyprinid herpesvirus type 3 in goldfish cohabiting with CyHV3-infected koi carp (Cyprinus carpio koi). Veterinary Record 161:792-793.

Gilad O, Yun S, Adkison MA, Way K, Willits NH, Bercovier H, Hedrick RP (2003) Molecular comparison of isolates of an emerging fish pathogen, koi herpesvirus, and the effect of water temperature on mortality of experimentally infected koi. J Gen Virol 84:2661-2668.

Goodwin A (2012) Herpesviruses in Fish. Southern Regional Aquaculture Center (SRAC) publication No. 4710, May 2012.

Haenen OLM, Way K, Bergmann SM, Ariel E (2004) The emergence of koi herpesvirus and its significance to European aquaculture. Bulletin of the European Association of Fish Pathologists 24:293-307.

Hedrick RP, O Gilad, S Yun, JV Spangenberg, GD Marty, RW Nordhausen, MJ Kebus, H Bercovier, and A Eldar (2000) A herpesvirus associated with mass mortality of juvenile and adult koi, a strain of common carp. Journal of Aquatic Animal Health 12:44-57.

Hedrick RP, Waltzek TB, McDowell TS (2006) Susceptibility of koi carp, common carp, goldfish, and goldfish x common carp hybrids to Cyprinid herpesvirus 2 and Cyprinid herpesvirus 3. Journal of Aquatic Animal Health 18:26-34.
Kempter J, Sadowski J, Schutze H, Fischer U, Dauber M, Fichtner D, Panicz R, Bergmann SM (2009) Koi herpes virus: do acipenserid restitution programs pose a threat to carp farms in the disease-free zones? Acta Ichthyologica Et Piscatoria 19:119-126.

Noga, E J (2010) Fish disease: diagnosis and treatment. Wiley-Blackwell, Ames, IA.

Office International des Epizooties (2012). Diseases listed by the OIE. Aquatic Animal Health Code, 15th Edition, OIE Aquatic Animal Health Standards Commission (Aquatic Animals Commission), Office International des Epizooties. Available: www.oie.int/eng/normes/fcode/ en_sommaire.htm. (September 2012)

Ornamental Aquatic Trade Association (OATA) (2001) Koi herpes virus (KHV). OATA, Westbury, Wilts, United Kingdom.

Perelberg, A, M Smirnov, M Hutoran, A Diamant, Y Bejerano, and M Kotler (2003) Epidemiological description of a new viral disease afflicting cultured Cyprinus carpio in Israel. The Israeli Journal of Aquaculture 55(1):5-12.

Petty, BD and WA Fraser (2005) Viruses of pet fish. Veterinary Clinics Exotic Animal Practice 8:67-84.

Pokorova, D, T Vesely, V Piackova, S Reschova and J Hulova (2005) Current knowledge on koi herpesvirus (KHV): a review. Vet Med-Czech 50(4):139-147.

Ronen, A, A Perelberg, J Abramovitz, M Hutoran, S Tinman, I Bejerano, M Steinitz, and M Kotler. (2003) Efficient vaccine against the virus causing a lethal disease in cultured Cyprinus carpio. Vaccine 21(32):4625-4743.

Sadler J, Marcecaux E, Goodwin AE (2008) Detection of koi herpesvirus (CyHV3) in goldfish, Carassius auratus (L.), exposed to infected koi. Journal of Fish Diseases 31:71-72.

Sano T, Morita N, Shima N, Akimoto M (1990) A preliminary report on pathogenicity and oncogenicity of cyprinid herpesvirus. Bull Eur Ass Fish Path 10:11-13.

Shimizu T, Yoshida N, Kasai H, Yoshimizu M (2006) Survival of koi herpesvirus (KHV) in environmental water. Fish Path 41:153-157.

St-Hilaire S, Beevers N, Joiner C, Hedrick RP, Way K (2009) Antibody response of two populations of common carp, Cyprinus carpio L., exposed to koi herpesvirus. J Fish Dis 32:311-320. 
St-Hilaire S, Beevers N, Way K, Le Deuff RM, Martin P, Joiner C (2005) Reactivation of koi herpesvirus infections in common carp Cyprinus carpio. Dis Aquat Org 67:15-23.

Petty, BD, AC Riggs, R Klinger, R Yanong, and R FrancisFloyd (2002) Spring viremia of carp. University of Florida, Institute of Food and Agricultural Sciences, Fact Sheet VM-142, Gainesville. Available: http://edis.ifas.ufl.edu/ VM106. (September 2008)

Perelberg A, Ilouze M, Kotler M, Steinitz M (2008) Antibody response and resistance of Cyprinus carpio immunized with cyprinid herpes virus 3 (CyHV3). Vaccine 26:3750-3756.

Waltzek, TB, G O Kelley, D M Stone, K Way, L Hanson, H Fukuda, I Hirono, T Aoki, AJ Davison and RP Hedrick (2005) Koiherpesvirus represents a third cyprinid herpesvirus (CyHV-3) in the family Herpesviridae. Journal of General Virology 86:1659-1667.

Waltzek TB, Kelley GO, Alfaro ME, Kurobe T, Davison AJ, Hedrick RP (2009) Phylogenetic relationships in the family Alloherpesviridae. Dis Aquat Org 84:179-194. 
Table 1. Comparison of koi herpesvirus (KHV), spring viremia of carp (SVC), and carp pox.

\begin{tabular}{|c|c|c|c|}
\hline & Koi Herpesvirus & Spring Viremia of Carp & Carp Pox \\
\hline Synonyms & $\begin{array}{l}\text { Cyprinid herpesvirus } 3 \text { (CyHV-3); } \\
\text { carp nephritis and gill necrosis } \\
\text { virus (CNGV) }\end{array}$ & Infectious dropsy of carp & $\begin{array}{l}\text { Cyprinid herpesvirus } 1 \text { (CyHV-1); koi } \\
\text { pox; carp herpes virus; herpesviral } \\
\text { epidermal proliferation in carp (HEPC); } \\
\text { herpesvirus septicemia in carp (HSC) }\end{array}$ \\
\hline Abbreviation & KHV; CyHV-3 & SVC; SVCV & $\mathrm{CHV} ; \mathrm{CyHV}-1$ \\
\hline Viral Agent & $\begin{array}{l}\text { Herpesvirus } \\
\text { (DNA virus) }\end{array}$ & $\begin{array}{l}\text { Rhabdovirus } \\
\text { Rhabdovirus carpio } \\
\text { (RNA virus) }\end{array}$ & $\begin{array}{l}\text { Herpesvirus } \\
\text { Herpesvirus cyprini } \\
\text { (DNA virus) }\end{array}$ \\
\hline Species Affected & $\begin{array}{l}\text { Common carp; } \\
\text { koi; other species may carry virus }\end{array}$ & $\begin{array}{l}\text { Common carp; koi; goldfish; grass } \\
\text { carp; bighead carp; silver carp; and } \\
\text { Crucian carp }\end{array}$ & Common carp; koi \\
\hline $\begin{array}{l}\text { Optimal Water } \\
\text { Temperature }\end{array}$ & $64-81^{\circ} \mathrm{F}\left(18-27^{\circ} \mathrm{C}\right)$ & $41-64^{\circ} \mathrm{F}\left(5-18^{\circ} \mathrm{C}\right)$ & $<68^{\circ} \mathrm{F}\left(<20^{\circ} \mathrm{C}\right)$ \\
\hline Transmission & $\begin{array}{l}\text { Direct contact; } \\
\text { fecal material; } \\
\text { infected water/mud; equipment; } \\
\text { vectors }\end{array}$ & $\begin{array}{l}\text { Direct contact; fecal material; } \\
\text { infected water/mud; equipment; } \\
\text { vectors }\end{array}$ & $\begin{array}{l}\text { Direct contact; fecal material; } \\
\text { infected water/mud; equipment; } \\
\text { vectors }\end{array}$ \\
\hline Age Susceptibility & $\begin{array}{l}\text { Young more susceptible than } \\
\text { mature }\end{array}$ & $\begin{array}{l}\text { Young more susceptible than } \\
\text { mature }\end{array}$ & Young more susceptible than mature \\
\hline \multicolumn{4}{|l|}{ Clinical Signs } \\
\hline Behavioral & $\begin{array}{l}\text { Lethargy; swim close to the } \\
\text { surface; respiratory distress; erratic } \\
\text { behavior }\end{array}$ & $\begin{array}{l}\text { Lethargy; low on tank or pond } \\
\text { bottom; awkward swimming }\end{array}$ & None \\
\hline External & $\begin{array}{l}\text { Gill necrosis; sunken eyes; notched } \\
\text { nose; secondary bacterial and } \\
\text { parasitic infections }\end{array}$ & $\begin{array}{l}\text { Exophthalmia; pinpoint skin } \\
\text { hemorrhage; abdominal distention; } \\
\text { mucus from vent }\end{array}$ & Smooth raised wart-like skin lesions \\
\hline Internal & Few, variable signs & $\begin{array}{l}\text { Edema; inflammation; pinpoint } \\
\text { hemorrhages of many organs } \\
\text { including swim bladder }\end{array}$ & None \\
\hline Testing Methods & $\begin{array}{l}\text { Direct methods (virus isolation and } \\
\text { PCR); indirect methods (ELISA and } \\
\text { VN) }\end{array}$ & $\begin{array}{l}\text { Direct methods (virus isolation and } \\
\text { PCR) }\end{array}$ & Direct methods (virus isolation) \\
\hline Carrier States & Yes & Yes & Yes \\
\hline Regulatory Status & $\begin{array}{l}\text { NOTIFIABLE with no mandatory } \\
\text { consequences }\end{array}$ & $\begin{array}{l}\text { NOTIFIABLE with mandatory } \\
\text { consequences; import regulations }\end{array}$ & None \\
\hline Treatment & None & None & None \\
\hline $\begin{array}{l}\text { Prevention/ } \\
\text { Control }\end{array}$ & $\begin{array}{l}\text { Depopulate infected stocks; } \\
\text { practice good biosecurity including } \\
\text { quarantine and testing; purchase } \\
\text { fish from known reputable source; } \\
\text { keep susceptible species separated }\end{array}$ & $\begin{array}{l}\text { Depopulate infected stocks; } \\
\text { practice good biosecurity including } \\
\text { quarantine; purchase fish from } \\
\text { known reputable source; keep } \\
\text { susceptible species separated }\end{array}$ & $\begin{array}{l}\text { Depopulation generally not } \\
\text { required for older fish; practice good } \\
\text { biosecurity including quarantine; } \\
\text { purchase fish from known reputable } \\
\text { source }\end{array}$ \\
\hline Disinfection & $\begin{array}{l}\text { Chlorine ( } 200 \text { ppm for } 1 \\
\text { hour); quaternary ammonium } \\
\text { compounds ( } 500 \text { ppm for } 1 \text { hour) }\end{array}$ & $\begin{array}{l}\text { Chlorine ( } 500 \mathrm{ppm} \text { for } 10 \text { minutes); } \\
\text { ozone; gamma/UV radiation; } \mathrm{pH} \\
<4.0 \text { or }>10.0 \text {; } \\
\text { heat } 60^{\circ} \mathrm{C} \text { for } 15 \mathrm{~min}\end{array}$ & $\begin{array}{l}\text { Chlorine ( } 200 \text { ppm for } 1 \text { hour); } \\
\text { quaternary ammonium compounds } \\
\text { (500 ppm for } 1 \text { hour) }\end{array}$ \\
\hline
\end{tabular}

